African Journal of Health, Safety and Environment

\title{
EFFECT OF DEORDORANT ON MICROFLORA OF THE ARMPIT OF UNIBEN FEMALE STUDENTS
}

\author{
*Ogbebor, I. M. \\ ${ }^{*}$ Department of Microbiology, Faculty of Life Sciences, University of Benin, Benin City, Edo State, Nigeria \\ *Corresponding Author's E-mail: itohanogbebor@gmail.com Phone: 08037378732
}

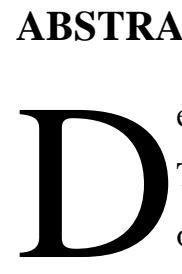

eodorants are substances formulated for the purpose of eliminating armpit odor but not perspiration.

They typically consist of alcohol. When applied, they make the skin acidic, preventing the proliferation of bacteria. This study was carried out with the aim of evaluating the effects of deodorant on microflora of the armpit. The study lasted for one month which was divided into two phases; Phase one consist of two weeks without deodorant usage and phase two consist of two weeks of deodorant usage. Axillae swabs were collected from 20 female students of the University of Benin. Samples were cultured and incubated at 37 ${ }^{\circ} \mathrm{C}$ both aerobically and anaerobically for 24 - 48 hours on Chocolate, Blood and MacConkey agars. The brand of deodorant used was 'Bouquet Deodorant'. Antibiotic susceptibility test was done on nutrient agar using the disc diffusion method of Bauer and Kirby. The isolates identified consist of Staphylococcus albus which was the predominant organism and accounted for $52.4 \%$ and $50 \%$ of the bacteria isolates for the first and second weeks respectively. Other bacteria isolated include Staphylococcus aureus (42.9\% and 46.1\%) and Klebsiella spp. $(4.7 \%$ and $3.9 \%)$ respectively for the successive two weeks. All the isolates showed some degree of susceptibility to impenem, gentamycin, ofloxacin, erythromycin, cloxacilin, amoxilillin and clavulanate. Staphylococcus aureus and Klebsiella showed some degree of susceptibility to cefuroxime while Staphylococcus albus was resistant. All the isolated showed some degree of susceptibility to ciprofloxicin while Staphylococcus aureus was resistant. The axillary microflora, predominantly Gram-positive cocci showed a sustained reduction during two weeks usage of deodorant and Gram-negative bacteria were, in general, eliminated.

Keywords: armpit, microflora, deodorant, gram-positive, gram-negative

LICENSE: This article by African Journal of Health, Safety and Environment (AJHSE) is licensed and published under the Creative Commons Attribution License 4.0 International License, which permits unrestricted use, distribution, and reproduction in any medium, provided this article is duly cited.

COPYRIGHT: The Author(s) completely retain the copyright of this published article.

OPEN ACCESS: The Author(s) approves that this article remains permanently online in the open access (OA) model

QA: This Article is published in line with "COPE (Committee on Publication Ethics) and PIE (Publication Integrity \& Ethics)". 


\section{INTRODUCTION}

The groups of bacteria that predominate almost every part of the skin are categorised into four, namely diphtheroids (e.g., corynebacteria like Corynebacterium, Diphtheria; Propionibacterium acnes); micrococci (which include Staphylococci such as Staphylococcus epidermidis); streptococci (either alpha $(\alpha)$ or gamma $(Y)$ hemolytic) and the enterococci. Besides bacteria, the skin is also known to habour yeast (e.g., Candida) and fungi (Barrett-Hill, 2004). Microbial populations vary over the body's skin. This variation is due to differences in $\mathrm{pH}$, oxygen, water and secretions. Specific groups, such as the diphtheroids have been known to occupy mainly the groin and armpits. The armpit harbours about 500,000 bacteria per square inch. Also, the forearm has been reported to harbour about 12,000 bacteria per square inch (Taylor et al., 2003). Since the 1950s it has been clear that the precise composition of the skin biome influences its effectiveness as a defensive layer against pathogens and contributes to bodily odors (Urban et al., 2016)

Commensal and symbiotic pathogenic microorganisms occupy the human skin with cellular densities within the range of $10^{6}$ per $\mathrm{cm}^{3}$ (Eugenie et al., 2010). The skin itself is comprised of several parts. Skin regions such as the axillae (armpit), perineum (groin) and toe webs are perfect breeding grounds for bacteria due to their moist nature. The human skin surface is mostly dry and is largely inhabited by Staphylococcus epidermidis and Propionibacterium (Barrett-Hill, 2004).

Body odours can originate from various sources such as axillae, perineum and toe webs. Axillary odor is the most common and stigmatized of these odours. Breakthroughs in the control of axillary malodour came in the late 1900 s when scientists were able to explain the structure and function of the human sweat glands (Eugenie $e t$ al., 2010). They also investigated the roles of bacterial microflora on the human skin. Their studies lead to odour management strategies for underarm secretions and skin bacteria such as reduction of perspiration by inducing blockage of sweat glands and reduction of microorganisms on body surface (Zeng et al., 1998). Body odour is influenced by the actions of the skin flora, including members of Corynebacterium, which manufacture enzymes called lipases that break down the lipids in sweat to create smaller molecules like butyric acid. These smaller molecules smell, and give body odour its characteristic aroma (Uzeh et al., 2012).

Earliest studies of human body odour revealed that odoriferous steroids 5a-androst-16-en-3-one and 5a-androst-16-en-3a-ol contributed to odour from human axillae secretions (Natch et al., 2004). Also, it was detected that volatile thiols, which are usually released from precursors due to the action of C-S-lyases also contributed to axillary malodor (Eugenie et al., 2010)

Axillary malodour is usually formed from the biotransformation of human secretions by the skin microbiota. In this process, odourless substrates are initially metabolized by commensal microbes which are resident on the axillary skin. Culture dependent investigation by Leaden et al. (1981) revealed axillary microbiota present in the skin to be of four bacteria phyla Staphylococcus, Micrococcus, Corynehacterium and Propionibacterium and also yeasts (Malessezia).

Deodorants are substances that can be applied to the body to reduce axillary odour through antibacterial action. They help to degrade apocrine axillary secretions while antiperspirants functions by reducing axillary odour and perspiration levels from the armpit making it dry and comfortable (Philip and Jack, 2000). They 
have both been of tremendous help to many who use them to mask body odour since their creation in the $19^{\text {th }}$ century. Research on deodorants is now becoming popular since more people use them on a regular basis to mask and prevent body odour. Despite their popularity, many people still have little knowledge about these products. Also, multiple reports on the possible harmful effects of these products circulate the media from time to time. This study was carried out with the aim of evaluating the effects of deodorants on the microflora of the armpit female students attending the University of Benin, Benin City.

\section{METHODOLOGY}

\section{SAMPLING MATERIALS}

Sterile swab sticks were used to collect samples from twenty volunteer female students in the University of Benin. Total swabs were given to volunteers considered in this research. The Bouquet deodorant was used in this research. The composition of this deodorant was: Water, Tiethylcitrate, Cyclomethicone, Ceteareth-12, Fragrance, Glycerin, Isopropyl Palmitate, Xanthan Gum, Aluminum Chlorohydrate, Triclosan, Trisodium Cittrate, Methylchloroisothiazolinone, Methylisothiazolinone and Sodium Hydroxide.

\section{SAMPLE COLLECTION}

Samples were collected from volunteers as from $2 \mathrm{pm}$ during maximum perspiration after seeking their opinions to be used in the study. Collection of samples spanned a period of one month. The first two weeks volunteers did not use deodorants and the next two weeks volunteers used same type of deodorant. Swab sticks were used to touch the axillae and thereafter stored for onward processing at the laboratory.

\section{STERILIZATION OF MATERIALS}

Glass-wares such as Petri dishes, test tubes, glass rod, measuring cylinder, beakers and conical flasks required for this research work were soaked and washed in detergent and rinsed with distilled water. They were wrapped with aluminum foil paper and dried in the oven in an inverted position at $160-170{ }^{\circ} \mathrm{C}$ for $45-60$ minutes. All the glass-wares used were manufactured in England by Pyrex.

\section{PREPARATION OF CULTURE MEDIA}

The media used were Nutrient agar, MacConkey agar, Blood agar and Chocolate agar. The media were all prepared according to manufacturers' instruction.

\section{CULTURING ORGANISM}

Swab stick containing samples was used to create a smear on media. MacConkey agar was inoculated first, chocolate next and blood agar last. Wire loop was flamed till red hot, allow cooling and used to streak out the smear created on the media. Quadrant streaking method was used and plates were incubated at $37{ }^{\circ} \mathrm{C}$ for 24 hours. 


\section{TESTS FOR IDENTIFICATION OF BACTERIA ISOLATES MORPHOLOGICAL CHARACTERISTICS}

Morphological characteristics of the bacterial isolates was carried out using Gram stain techniques as described by Cheesbrough (2000). Gram staining techniques was done on the basis of the component of the cell wall. Organisms which retain the colour of the initial stain are known as gram-positive organism, while those which do not retain the primary stain when decolourised by gram alcohol are gram negative organism. Gram positive organisms appeared purple while Gram negative organisms appeared redincolor.

\section{BIOCHEMICAL TEST}

Biochemical test was performed on bacteria isolates using standard test techniques such as catalase, coagulase test, citrate utilization test, indole test, oxidase test and urease utilization test,

\section{ANTIBIOTICS SUSCEPTIBILITY TESTING}

Colonies of microorganism were collected with a wire loop and emulsified completely in normal saline. This was poured on nutrient agar in a Petri dish. Normal saline was allowed to floor the agar, thereafter excess saline was poured off. Antibiotic sensitivity disc was placed on nutrient agar and incubation was carried out for $24 \mathrm{hr}$. The different antimicrobial agents used were imipenem, gentamycin, cefuroxime, ofloxacin, erythromycin, amoxicilin clavulanate, ciprofloxacin and cloxacilin. The zones of inhibition were measured to determine sensitive and nonsensitive organisms. "R" was used to represent resistance, while "S" was used to represents sensitivity to the antibiotic. Results obtained were presented descriptively (CLSI, 2014).

\section{RESULTS}

Isolates identified consist of bacterial belonging to three different species as shown in Table 1. The identified bacteria include Staphylococcus aureus, Staphylococcus albus and Klebsiella sp. All bacterial isolates were facultative anaerobic in nature. Gram-positive cocci were predominant accounting for $95.3 \%$ and $96.1 \%$ of the total isolates, for the first and second two weeks respectively. Gram-negative rods were found in $4.7 \%$ and $3.9 \%$ of isolates for the first and second two weeks respectively.

As shown in Table 2 and Table 3, Staphylococcus albus was the most predominant organism and accountsedfor $52.4 \%$ of the bacteria isolates in the first two weeks and $50 \%$ of the bacteria isolates in the second two weeks. Other bacteria isolated from the axillae region includes Staphylococcus aureus (42.9\% and $463.1 \%)$ and Klebsiella spp. (4.7\% and $3.9 \%$ ) respectively for the successive two weeks.

Table 4 reveals the result for effects of two weeks deodorant usage on axillae bacteria isolates/ The bacteria distribution on the skin before application of deodorant ranged from $9.01 \times 10^{2}-12.12 \times 10^{2} / \mathrm{cm}^{2}$ skin while bacteria distribution on the skin after application of deodorant ranged from $2.16 \times 10^{2}-9.60 \times 10^{2} / \mathrm{cm}^{2} \mathrm{skin}$. 
The sensitivity of the isolates to different antibiotics is shown in table 5. All the isolates showed some degree of susceptibility to imipcnem, gentamycin, ofloxacin, erythromycin, cloxacilin, amoxicillin clavulanate. Staphylococcus aureus and Klebsiella showed some degree of susceptibility to cefuroxime while Staphylococcus albus was resistant. All the isolates showed some degree of susceptibility to ciprofloxacin while Staphylococcus aureus was resistant.

Table 1: Summary of Cultural, Morphological and Biochemical characteristics of Bacterial isolates

\begin{tabular}{llll}
\hline Characteristics & Bl & B2 & B3 \\
\hline Cultural Elevation & Convex & Convex & Low convex \\
Margin & Entire & Entire & Entire \\
Colour & Yellow & Yellow & Cream \\
Shape & Circular & Circular & Circular moist \\
Surface appearance & Dry & Dry & \\
Morphological & & & \\
Gram Stain & & & \\
Cell type & + & + & - \\
Cell Arrangement & Cocci & Cocci & $\mathrm{R}$ \\
Biochemical & Cluster & Cluste & $\mathrm{O}$ \\
Catalase & & $\mathrm{r}$ & $\mathrm{i}$ \\
Coagulase & & & \\
Citrate & + & + & + \\
Urease & + & - & + \\
Indole & + & + & + \\
Oxidase & + & + & + \\
Hemolysis & - & - & - \\
\hline
\end{tabular}

Key: B1 = Staphylococcus aureus, B2 = Staphylococcus albus, B3 = Klebsiella sp. 
Table 2: Percentage of Occurrence of the Various Bacterial Isolates for the Respective First

Two Weeks

\begin{tabular}{lll}
\hline Bacterial isolates & Number of isolates & Percentage of occurrence (\%) \\
\hline Staphylococcus aureus & 82 & 42.9 \\
Staphylococcus albus & 100 & 52.4 \\
Klebsiella spp. & 9 & 47 \\
\hline
\end{tabular}

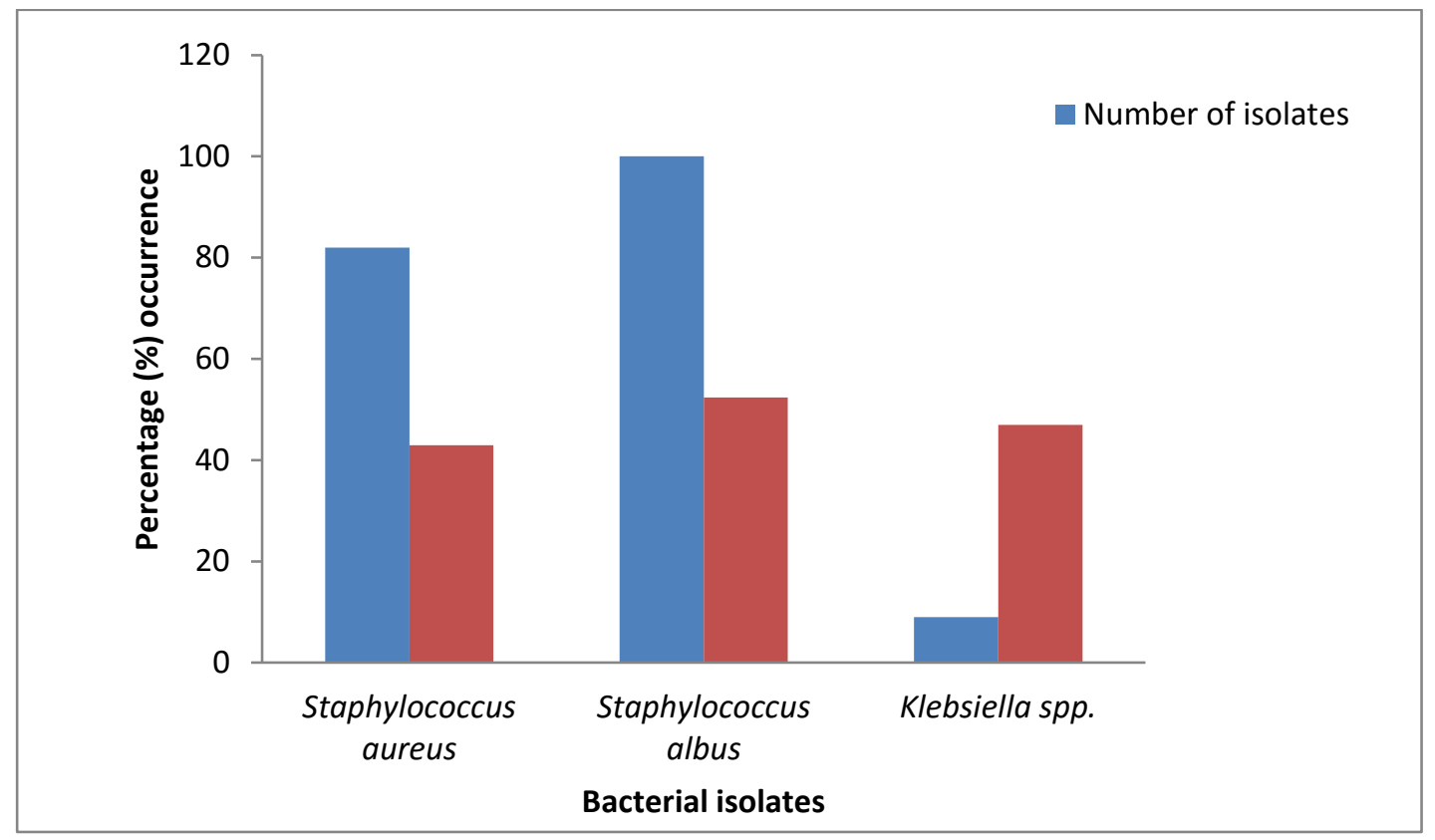

Figure 1: Graphical representation of the percentage of occurrence of the various bacterial isolates for the first two weeks

Table 3: Percentage of Occurrence of the Various Bacterial Isolates for the Second Two weeks (with the use of deodorant)

\begin{tabular}{lll}
\hline Bacterial isolates & Number of isolates & Percentage of occurrence (\%) \\
\hline Staphylococcus aureus & 82 & 46 \\
Staphylococcus albus & 89 & 50 \\
Klebsiella spp. & 7 & 3.9 \\
\hline
\end{tabular}




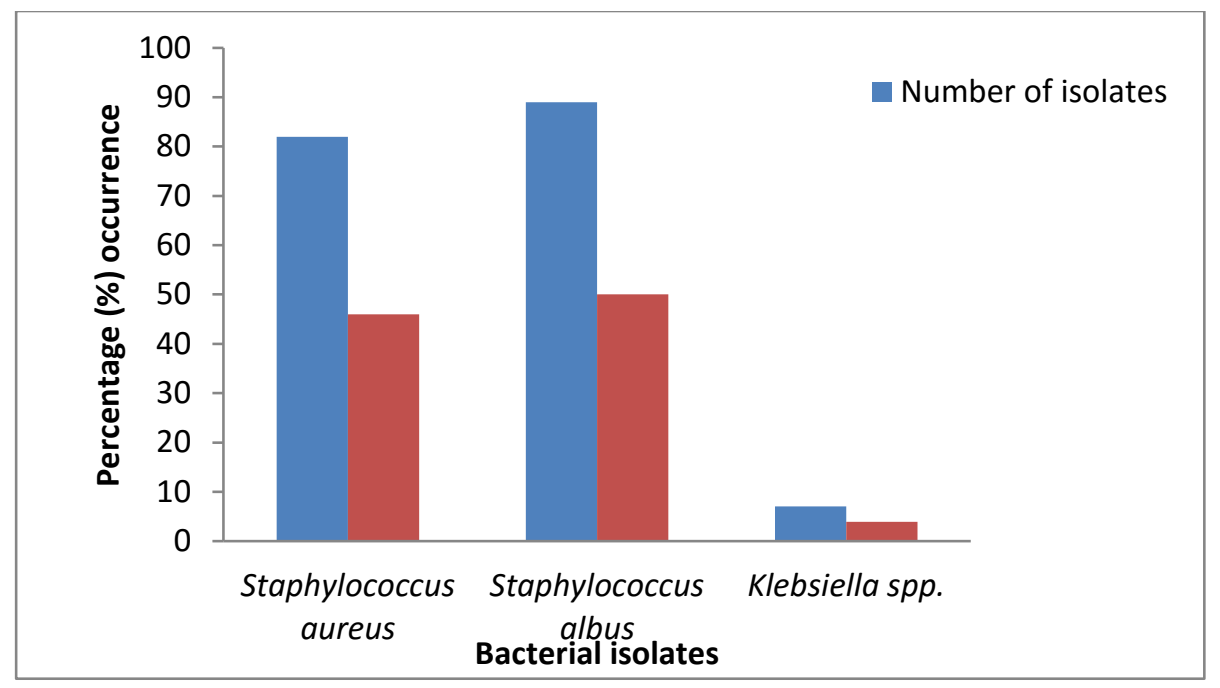

Figure 2: Graphical representation of the percentage of occurrence of the various bacterial isolates for the second two weeks

Table 4: Effects of Two Weeks Deodorant Usage on Axillae Bacteria Isolates

\begin{tabular}{|c|c|c|}
\hline \multirow[t]{2}{*}{ Application period } & \multicolumn{2}{|c|}{ Bacteria isolates $/ \mathrm{cm}^{2}$ skin } \\
\hline & Before application $\left(10^{2}\right)$ & During application $\left(\mathbf{1 0}^{2}\right)$ \\
\hline Day 1 & 9.11 & 9.60 \\
\hline Day 2 & 9.78 & 7.81 \\
\hline Day 3 & 8.79 & 4.85 \\
\hline Day 4 & 7.05 & 5.12 \\
\hline Day 5 & 9.01 & 3.93 \\
\hline Day 6 & 12.12 & 3.95 \\
\hline Day 7 & 10.48 & 3.56 \\
\hline Day 8 & 10.82 & 3.64 \\
\hline Day 9 & 9.95 & 2.68 \\
\hline Day 10 & 9.76 & 2.16 \\
\hline
\end{tabular}

Table 5: Antibiogram of the Bacterial Isolates

\begin{tabular}{llllllllll}
\hline Isolates & No. & IPM & CN & CXM & OFX & E & AUG & CIP & OB \\
\hline Staphylococcus aureus & 164 & 153 & 132 & 155 & 148 & 147 & 195 & Nil & 39 \\
& & & & & & & & & \\
& & $93.3 \%$ & $80.5 \%$ & $94.5 \%$ & $90.2 \%$ & $89.6 \%$ & $64 \%$ & & $23.8 \%$ \\
Staphylococcus albus & 189 & 172 & 117 & Nil & 147 & 175 & 104 & 61 & 179 \\
& & $91 \%$ & $61.9 \%$ & & $77.8 \%$ & $92.6 \%$ & $55 \%$ & $32.3 \%$ & $94.7 \%$ \\
$\begin{array}{l}\text { Klebsiella spp. } \\
\text { Test isolates }\end{array}$ & 16 & 16 & 14 & 12 & 8 & 1 & 4 & 2 & 1 \\
\hline
\end{tabular}

Key: IPM = Imipencm CN: Gentamcycin, CXM: Cefuroxime, OFX = Oflaxocin, E=Erythromycin, AUG= Amoxicilin clavulanate, $\mathrm{CIP}=$ Ciprofloxacin, $\mathrm{OB}=$ Cloxacillin 


\section{DISCUSSION AND CONCLUSION}

Previous studies have demonstrated that unwashed axillae consist of a fairly constant microbial population over three days, varying from $4.9 \times 10^{4}$ to $5.9 \times 10$ bacteria/cm skin ${ }^{2}$. When the axillae are washed with soap, the microbial count is initially reduced, but the intermediate counts each day show a buildup, with the axillary population increasing up to the unwashed level by the end of the day (Fearnley and Cox, 1983). The same tendency is evident following three days application of an ethanol-based aerosol spray, although the initial reduction in microbial count is much greater, presumably due to the intrinsic antibacterial action of the alcohol itself (Ashley, 1987).

Prior to use of deodorant (roll-on) by volunteers in this study it was observed that the total aerobic bacteria count had an average value of $4.73 \times 10^{3} / \mathrm{cm}^{2}$ skin (Table 3). Of the twenty test subjects, $8.6 \%$ carried Gramnegative bacteria in the axillae, in particular Klebsiella spp. The Gram-negative bacteria were eliminated following deodorant application, suggesting that in this case Gram-negative carriage was only of a transient nature. With nineteen of the twenty subjects, a simplification of the Gram-positive microflora was evident with deodorant usage, Staphylococcus spp. predominating. From 379 primary isolates characterized during the course of the study, 191. 4 $\%$ could be identified to belong to the predominant genera, Staphylococcus. Antibacterial efficacy of the deodorant was believed to be significantly enhanced prior to the active ingredients such as triclosan which slow bacterial growth, aluminum chlorohydrate that promote underarm dryness, etc. particularly following repeated application. This study clearly showed that Staphylococcus albus is the predominant organism in swab specimens resistant. All the isolates showed some degree of susceptibility to ciprofloxicin while Staphylococcus aureus was resistant.

Humans sweat as a means of thermoregulation to prevent body temperature elevation when heat is generated by strenuous activity, sweat when left to sit can produce a strong odour contributing heavily to the scent known as body odour (Sadahiko et al., 2010). Hence, a wash in the morning cannot efficiently prevent body odour all day which is caused by bacterial growth that use the secretion from apocrine, eccrine and sebaceous glands as the source of nutrient. The produced malodour is characteristic for each person depending on many factors such as skin structures, food eaten and types of bacteria. In order to prevent this body odour and to significantly reduce the growth by microorganism on the microflora of the armpit which is the major site of malodour in human, cosmetic products called antiperspirants and deodorants were introduced.

This study has provided evidence to show the efficacy of the use of deodorant by helping to prevent body odour and significantly reducing microbial population of the axillae. Therefore, as a form of suggestion we should pay attention to personal hygiene by bathing frequently and paying special attention to underarms using underarm deodorants.

\section{CONFLICT OF INTEREST}

The author has not declared any conflict of interests. 


\section{REFERENCES}

Ashley, R.C. (1987). Efficacy of the antimicrobial agent triclosan in topical deodorant products; recent developments in vivo. Journal of Societal Cosmetics and Chemistry 38: 223-231.

Barrett-Hill, F. (2004). Advanced Professional Skin Care: Understanding Skin Physiology. Virtual Beauty, New Zealand. ISBN 0-476-00665-1

Clinical and Laboratory Standards Institute (CLSI) (2014). Performance Standards for Antimicrobial Susceptibility Testing, Twenty-Fourth Informational Supplement, CLSI document M100-S24. Wayne, PA: CLSI.

Eugenie, F., Iris. B., Jens, S. and Andreas, T. (2010). Metatranscriptome analysis of the human armpit microbiota. Industrial Biotechnology 11: 1-5.

Fearnley, G. and Cox, A.R. (1983). A new microbiological approach to the assessment-of underarm deodorants. International Journal of Cosmetic Science 5: 97-109.

Leaden. J. I, McGinley, K.J. and Hoelzle, K. (1981). The microbiology of the human axillae and its relation to axillary odours. Journal of Investigational Dermatology 11: 413-416.

Natsch, A., Schmid, J. and Flaschmann (2004). Identification of odoriferous sulfanylalkanols in human axilla secretions and their formation through cleavage of cysteine precursors by a C-S lyase isolated from axilla bacteria. Chemical Biodiversity 1: 1058-1072.

Ojih, F.E., Okon, O.G., Nwanna, V.N., Udosen, I.J. and Abraham, N.A. (2014). Incidence of Staphylococcus aureus isolated from armpits of students of University of Abuja, Nigeria. International Journal of Research 1(10): 992-1003.

Philip, K. and Jack, W. (2000). Antiperspirants and deodorants. Poucher's Perfumes, Cosmetics and Soaps 10: 69-100.

Sadahiko, V., Kunihide, H. and Masatoshi. K. (2010). Odor associated with aging. Ami-Aging Medicine 7(6): 60-65.

Taylor, D., Daxlldy, A. and Grimshaw, S. (2003). Characterization of the microflora of the human axilla. International Journal of Cosmetic Science 25: 137-145.

Urban, J., Fergus, D.J., Amy, M.S., Megan, E., Holly, L.M., Robert, R.D. and Horvath, J.E. (2016). The effect of habitual and experimental antiperspirant and deodorant product use on the armpit microbiome. Peer Journal 10: 1-20.

Zeng, X., Dickinson, R. E. and He, Y. (1998). Effect of surface sublayer on surface skin temperature and fluxes. J. Climate, 11: 537-550. 